\title{
Agronomic Attributes of Five Okra Landraces Selected for Okra Production in Oyi Local Government Area of Anambra State, Nigeria
}

\author{
E.E. Okoli* \\ Department of Crop Science and Horticulture, \\ Chukwuemeka Odumegwu Ojukwu University, P.M.B. 6059 Awka, Anambra State \\ *correspondence: Dr. Evans Ebuka Okoli; ee.okoli@coou.edu.ng
}

\begin{abstract}
A research study on the agronomic attributes of five okra genotypes for Okra production were evaluated for growth and yield at the teaching and research farm of the Department of Crop Science and Horticulture, Faculty of Agriculture, Chukwuemeka Odumegwu Ojukwu University (COOU) Igbariam Anambra state. The experiment was conducted using a randomized complete block design (RCBD) with 4 replications using $3 \mathrm{~m}$ row plots. The total field size was $187 \mathrm{~m}^{2}(0.00187 \mathrm{ha})$ and a plant spacing of $0.60 \mathrm{~m} \times 0.30 \mathrm{~m}$ was used. There was no significant difference in the treatment means for all the parameter studied, however, result from the seedling characteristics revealed that Nkwelle Okra was the earliest to emerge (4.25 days) while Awkuzu okra was the last to emerge (6.00 days). The experiment showed that Awkuzu okra was earliest to flower at 60.30 days after planting while Nteje Okra was the last to reach $50 \%$ flowering at 70.10 days after planting. Awkuzu Okra had the highest number of pods per plant (11.80), pod weight $(50.90 \mathrm{~g})$ and yield $\mathrm{t} / \mathrm{ha}(0.00005 \mathrm{t} / \mathrm{ha})$ while the least was Nteje Okra for number of pods per plants (6.50), pod weight $(29.60 \mathrm{~g})$ and yield $\mathrm{t} / \mathrm{ha}(0.000029 \mathrm{t} / \mathrm{ha})$. Therefore, a further genetic study was recommended for the studied genotypes to produce hybrid and synthetic cultivar for the production of okra in the study area.
\end{abstract}

Keywords: agronomic attribute; landraces; okro; oyi local government; anambra state

\section{INTRODUCTION}

Okra (Abelmoschus esculentusL.Moench) belongs to the plant family Malvacea which also contains various plants and fruits like the marshmallow, but it is the most common and widely cultivated crop in this family (Richard, 2017).

The plant is cultivated in tropical, subtropical and warm temperate regions around the world (National Research Council, 2006). It is mostly cultivated because of its fibrous fruits or pods containing round, white seeds. Also, it is among the most heat and drought tolerant vegetable species in the world and will tolerate soils with heavy clay and intermittent moisture (Growing Okra-Department of Primary Industries and fisheries, Queensland, 2007).

In Nigeria there are two distinct seasons for okra production; the rainy and dry season. It is usually more abundant during the rainy season than the dry season due to the fact that it is mostly cultivated on a small scale by small peasant farmers who lack the funds to setup irrigation facilities for dry season production (Adenijiet al, 2007).

Okra serves as a major economic crop in the West African sub-region owing to its vital importance as a component of various recipes in many local delicacies. In terms of nutrition, tender green pods of okra are important sources of vitamins A, B, C and K, folic acid, potassium, magnesium, calcium and trace elements such as copper, manganese, iron, zinc, nickel, and iodine which most times is deficient in the diet of people in most developing countries. Okra has medicinal values as it contains high levels of antioxidants such as $\beta$-carotene, xanthin and lutein (lee kit et al, 2000). The mucilage substance gotten from okra pods has been found to have a good alkaline $\mathrm{pH}$, which contributes to the cure of gastrointestinal ulcer by neutralizing the digestive acid in the stomach (Wamanda, 2007).

Despite all these economic benefits, okra is yet to reach its maximum yield potential because of several factors. They include they use of locally unimproved variety, high incidence of pests and diseases, lack of irrigation for the small peasant farmers etc. Thus, enough attention needs to be given towards selecting high yielding cultivars of okra and ways to improve their agronomic characteristics. Therefore, the objective of this work is to determine the agronomic characteristics of five landraces of okra selected for production in Oyi Local Government Area of Anambra state.

\section{MATERIALS AND METHODS}

\section{Experimental site}

The experiment was conducted at the Teaching and Research farm of the Department of Crop Science and Horticulture, Faculty of Agriculture, Chukwuemeka Odumegwu Ojukwu University (COOU) Igbariam, Anambra state. Igbariam falls within the derived Savannah Zone of Nigeria and is located at Latitude of $06^{\circ}$ and $45^{\circ} \mathrm{E}$. The soil series are utisols and belongs to the Sandy loam textural class.

\section{Experimental design and field layout}

Okro seeds were collected from Umuobi-Awkuzu, OdumoduAni-Umunya, Amawa-Ogbunike, Ifite-Nkwelle, Ikenga-Nteje and evaluated using Randomized Complete Block Design (RCBD) with four replications using $3 \mathrm{~m}$ row plots. The experimental area is $17 \mathrm{~m} \mathrm{X} 11 \mathrm{~m}\left(187 \mathrm{~m}^{2}\right)$ in size. 
The whole area was divided into four blocks with the spacing of $1 \mathrm{~m}$ between each block. Each block contained five treatments with an inter-row spacing of $0.60 \mathrm{~m}$ and Intra-row spacing of $0.30 \mathrm{~m}$ with the row $3 \mathrm{~m}$ long. The okro was planted under rain-fed conditions.

TABLE 1: Source of Landraces

\begin{tabular}{ll}
\hline Landrace Code & Site of Collection \\
\hline AWK 1 & Umuobi- Awkuzu \\
UMU 1 & Odumodu-Ani-Umunya \\
OGBU 1 & Amawa-Ogbunike \\
NKWE 1 & Ifite-Nkwelle \\
NTE 1 & Ikenga-Nteje \\
\hline
\end{tabular}

\section{Data collection}

Data was collected on the following Parameters:

(i) Number of days to $50 \%$ emergence: This was determined by recording the number of days it took half of the plant in the plot to emerge.

(ii) Number of leaves: This was obtained as the average count of the number of leaves from four randomly selected plants per plot at 4,6,8 WAP.

(iii) Stem girth: Here the measurement of the diameter of the stem of the okra at the base was determined using Vernier caliper.

(iv) Number of branches per plant: This was obtained by counting the number of branches of four sample plant in each plot at 4, 6, 8 WAP.

(v) Number of days to 50\% flowering: It will be determined by recording the number of days it took half of the okra plant in a plot to flower.

(vi) Plant height at 50\% flowering: This was measured as the distance from the base of okra plants to the base of the flag leaf.

(vii) Number of plant at harvest: Data was collected on the total number of plants surviving up to the time of harvest in each plot.

(viii) Number of pod per plant: Data was collected on the number of pods on each plant per plot.

(ix) Pod weight (g): Measurement was taken as the weight in gram of all okra in each plot.

(x) Yield (t/ha): This was measured in tons per hectare of okra harvested in each plot.

\section{Statistical analysis}

The data collected were subjected to Analysis of Variance (ANOVA) using Gen. Stat Release 10.3 statistical software. The means will be compared using Fisher's least Significance Difference (F-LSD) as described by (Obi, 2002).

\section{RESULTS}

\section{Seedling Characteristics of Okra Genotypes}

From table 2 below it was observed that Nkwele Okra from Ifite-Nkwelle were the earliest in emergence at 4.25 days, emergence was recorded for Nteje Okra, Ogbunike okra, Umunya Okra, and Awkuzu Okra at 4.50, 4.50, 5.50 and 6.00 respectively. However, there was no significant difference between them in terms of days to $50 \%$ emergence ( $p>0.05)$.
For Number of plants established, the difference was not significant as shown in table 2. Awkuzu okra from UmobiAwkuzu had the lowest established plants (5.50), while Nkwele Okra from Ifite-Nkwelle had the highest established plants (7.25).

TABLE 2: Seedling characteristics of five okra genotypes grown in Igbariam, Southeastern Nigeria.

\begin{tabular}{lcc}
\hline Landraces & $\begin{array}{c}\text { Days to 50\% } \\
\text { Emergence }\end{array}$ & $\begin{array}{c}\text { Number of Plants } \\
\text { established }\end{array}$ \\
\hline Awkuzu Okra & 6.00 & 5.50 \\
Nkwele Okra & 4.25 & 7.25 \\
Nteje Okra & 4.50 & 5.75 \\
Ogbunike Okra & 4.50 & 6.50 \\
Umunya Okra & 5.50 & 5.75 \\
LSD (0.05) & NS & NS \\
\hline
\end{tabular}

LSD: Least significant difference, N.S: Not significant.

\section{Agronomic Characteristics of Okra Genotypes}

\section{Number of leaves}

The results obtained in number of leaves showed that the differences in treatment means were not significant ( $>0.005$ ) as shown in table 3 . The number of leaves at 4 weeks after planting revealed that Umunya Okra from Odumodu-Ani-Umunya produced the highest number of leaves (6.56) while the lowest was Nteje Okra from IkengaNteje (6.00).

At 6 weeks after planting, Umunya okra also recorded the highest (14.26) while Nkwele Okra recorded the lowest (11.06). At 8 weeks after planting however, Ogbunike Okra was the highest (22.80) while Nteje Okra recorded the lowest (18.60).

TABLE 3: Number of leaves of okra genotypes at 4, 6, 8 weeks after planting

\begin{tabular}{lccc}
\hline Landraces & $\begin{array}{c}\text { Number } \\
\text { of leaves } \\
\text { 4 WAP }\end{array}$ & $\begin{array}{c}\text { Number } \\
\text { of leaves } \\
\text { 6 WAP }\end{array}$ & $\begin{array}{c}\text { Number } \\
\text { of leaves } \\
\text { 8 WAP }\end{array}$ \\
\hline Awkuzu Okra & 6.25 & 13.63 & 21.00 \\
Nkwele Okra & 6.31 & 11.06 & 20.20 \\
Nteje Okra & 6.00 & 11.81 & 18.60 \\
Ogbunike Okra & 6.50 & 13.19 & 22.80 \\
Umunya Okra & 6.56 & 14.26 & 22.10 \\
LSD (0.05) & NS & NS & NS \\
\hline
\end{tabular}

LSD: Least significant difference, N.S: Not significant, WAP: Weeks after planting.

\section{Stem girth}

Stem Girth of a plant shows the lodging resistant of that plant to wind or other climatic factors. Table 4 revealed that there was no significant difference in the stem girth of the plants in all the studied genotypes.

At 4 weeks after planting, the genotype with the highest stem girth was Umunya Okra (2.51) while the lowest was the Awkuzu Okra from Umuobi-Awkuzu (1.13).

At 6 weeks after planting, Nkwele Okra was the highest (4.19) while Awkuzu Okra remained the lowest (3.25).

At 8 weeks after planting, Umunya Okra was also the highest (5.48) while Awkuzu Okra was the lowest (4.12). 
TABLE 4: Stem girth of okra genotypes at 4, 6, and 8 weeks after planting.

\begin{tabular}{lccc}
\hline Landraces & $\begin{array}{c}\text { Stem Girth } \\
\text { 4 WAP }\end{array}$ & $\begin{array}{c}\text { Stem Girth } \\
\text { 6 WAP }\end{array}$ & $\begin{array}{c}\text { Stem Girth } \\
\text { 8 WAP }\end{array}$ \\
\hline Awkuzu Okra & 1.13 & 3.25 & 4.12 \\
Nkwele Okra & 1.62 & 4.19 & 5.47 \\
Nteje Okra & 1.40 & 3.35 & 4.87 \\
Ogbunike Okra & 1.20 & 3.51 & 4.62 \\
Umunya Okra & 2.51 & 3.75 & 5.48 \\
LSD (0.05) & NS & NS & NS \\
\hline
\end{tabular}

LSD: Least significant difference, N.S: Not significant, WAP: Weeks after planting.

\section{Number of branches}

Analysis of Variance (ANOVA) showed that the differences in the treatment means were not significant for the number of branches of the studied Okra genotypes (table 5). At 4 weeks after planting Ogbunike Okra from AmawaOgbunike had the highest number of branches (4.12) while the lowest was Umunya Okra (5.33). At 6 weeks after planting, Nkwelle-Okra recorded the highest (10.88) while the lowest was the Nteje Okra (9.31). At 8 weeks after planting, Ogbunike had the highest number of branches (15.56) while Nteje okra recorded the lowest number of branches (12.38).

\section{Plant height at 50\% flowering (cm)}

There was no significant difference in the height of the various plants at $50 \%$ flowering table 5 . However, the highest plant height was observed in Nteje okra $(82.00 \mathrm{~cm})$ while the lowest plant height was observed in Awkuzu okra $(32.70 \mathrm{~cm})$.

TABLE 5: Number of branches of Okra Genotypes at 4, 6, and 8 Weeks after Planting and Plant Height at Flowering.

\begin{tabular}{lcccc}
\hline Landraces & $\begin{array}{c}\text { Number } \\
\text { of } \\
\text { branches } \\
\text { 4 WAP }\end{array}$ & $\begin{array}{c}\text { Number } \\
\text { of } \\
\text { branches } \\
\text { 6 WAP }\end{array}$ & $\begin{array}{c}\text { Number } \\
\text { of } \\
\text { branches } \\
\text { 8 WAP }\end{array}$ & $\begin{array}{c}\text { PH } \\
\text { at } \\
\text { FL } \\
\text { (cm) }\end{array}$ \\
\hline Awkuzu Okra & 5.44 & 9.82 & 13.25 & 32.70 \\
Nkwele Okra & 5.50 & 10.88 & 14.62 & 79.20 \\
Nteje Okra & 5.50 & 9.31 & 12.38 & 82.00 \\
Ogbunike Okra & 4.12 & 10.06 & 15.56 & 63.20 \\
Umunya Okra & 5.33 & 10.70 & 15.51 & 56.30 \\
LSD (0.05) & NS & NS & NS & NS \\
\hline
\end{tabular}

LSD: Least significant difference, NS: Not significant, WAP: Weeks after Planting, PH: Plant height, FL: Flowering.

\section{Yield characteristics of okra genotypes}

\section{Days to 50\% flowering}

The results in table 6 revealed that there was no significant difference $(p>0.05)$ in the days to $50 \%$ flowering of the okra plants. Awkuzu okra was earliest in flowering (60.30) while the. ate flowering genotype among all the genotypes was Nteje (70.10).

\section{Number of plant at harvest}

There was no significant difference amongst the treatment means for the number of plants at harvest (Table 6). Nkwele okra had the highest rate of plant at harvest (7.25), while Umunya Okra and Awkuzu okra had the lowest rate of plant at harvest (5.50).

\section{Number of pod per plant}

There was no significant difference amongst the treatment means for the number of pod per plant (Table 6); however, Awkuzu Okra produced the highest number of pod per plant (11.80) while the lowest was Nteje okra (6.50).

\section{Pod weight (g)}

There was no significant difference amongst the treatment means for the pod weight $(\mathrm{p}>0.05)$. However, Table 6 showed that Awkuzu okra has the highest pod weight $(50.90 \mathrm{~g})$ while the lowest pod weight was observed in Nteje okra (29.60g).

\section{Yield (t/ha)}

There was no significant difference amongst the treatment means for okra yield ( $p>0.05)$. Table 6, however, revealed that Awkuzu okra had the highest yield (0.00005t/ha) while the lowest in yield was obtained in Nteje Okra (0.000029t/ha).

TABLE 6: Mean Yield Characteristics of 5 okra genotypes grown in Ultisol of Igbariam, Anambra State, Nigeria.

\begin{tabular}{lccccc}
\hline \multicolumn{1}{c}{ Landraces } & $\begin{array}{c}\text { Days } \\
\text { to } \\
\mathbf{5 0 \%}\end{array}$ & $\begin{array}{c}\text { NOP at } \\
\text { Harvest }\end{array}$ & $\begin{array}{c}\text { NOPD } \\
\text { per } \\
\text { plant }\end{array}$ & $\begin{array}{c}\text { Pod } \\
\text { Weight } \\
\text { (g) }\end{array}$ & $\begin{array}{c}\text { Yield } \\
\text { (t/ha) }\end{array}$ \\
\hline Awkuzu Okra & 60.30 & 5.50 & 11.80 & 50.90 & 0.00005 \\
Nkwele Okra & 69.20 & 7.25 & 10.20 & 42.10 & 0.000042 \\
$\begin{array}{l}\text { Nteje Okra } \\
\text { Ogbunike }\end{array}$ & 70.10 & 5.75 & 6.50 & 29.60 & 0.000029 \\
$\begin{array}{l}\text { Okra } \\
\text { Umunya }\end{array}$ & 61.80 & 6.50 & 11.20 & 44.10 & 0.000044 \\
Okra & 68.20 & 5.50 & 10.50 & 36.20 & 0.000036 \\
LSD (0.05) & NS & NS & NS & NS & NS \\
\hline
\end{tabular}

LSD: Least significant difference, NS: Not significant,

FL: Flowering, NOP: Number of plants, NOPD: Number of pod

\section{DISCUSSION}

Knowledge about germplasm diversity and relationships among diverse germplasm is useful for plant breeders because it assists them to select suitable parents for crossing (Dwivedi et al. 2001).

The genetic constitution of crops does not change in different environments with respect to qualitative traits. However, measurable characters which are controlled by many genes, such as yield, plant height, leaf area, etc. are affected by changes in environments (Ngwuta et al., 2015). Although all the differences observed in the treatment means for the seedling, growth and yield parameters of the experiment appeared not to be significant for the five okra genotypes studied, the study is still very essential for further cross-breeding purposes.

Though ANOVA revealed that there was no significance difference among the five okra genotypes, from the tables for seedling characteristics and agronomic characteristics of the genotypes, it indicated that variability exists to allow identification of local germplasm with reasonable levels of desirable agronomic characteristics. This observation supports the earlier report of Ngwuta et al., (2001) that locally available germplasm can serve as sources of hybrid maize development.

The ultimate goal of a plant breeding program is higher yield. The result from this study showed variation amongst okra genotypes for in terms of plant stand at harvest, number of pods per plant, pod weight and yield in tons per hectare. 
Though this variation is not significant, the result agrees with Nwangburuka et al (2007) that studied twenty-nine varieties of okra for genetic variability and heritability using correlation studies. They found that the positive and significant phenotypic and genotypic correlation between plant height at maturity, fresh pod width, seeds per pod, and pods per plant, branches per plant with seed weight per plant and pod weight per plant. It was suggested that selection based on these phenotypic characters will lead to high seed and pod yield in okra.

\section{CONCLUSION}

The experiment revealed that Awkuzu okra had the highest number of yield output, followed by Ogbunike okra, genetic studies should be conducted among all the five genotypes using diallel mating to know the heterosis, combining ability, correlation coefficient of the agronomic attributes and other genetic parameters. The study revealed the days to $50 \%$ emergence and $50 \%$ flowering for the five okro landraces which is essential information for knowing when to plant each genotype for crossbreeding purposes.

\section{REFERENCES}

[1] Adeniji 0.T, Kehinde O.B, Ajala M.O, Adebisi M.A (2007). Genetic studies on Seed Yield of West African Okra (Abelmoschus caillei (A.chev) Stevels ). Journal of Tropical Agriculture 45: 36-41.

[2] Dwivedi, S.L., Gurtu, S., Chandra, S., Yuejin, W. \& Nigam, S.N. (2001). Assessment of genetic diversity among selected groundnut germplasm. I. RAPD analysis. Plant Breeding 120, 345-349.

[3] Growing Okra. Department of Primary Industries and Fisheries, Queens land. September 2007.

[4] Lee Kit, Cho CY, Yoon Si, Park Sk (2000). The Effect of Nitrogen Fertilizer Plant density.Wikipaedia.org.

[5] National Research Council, (2006). Lost crops of Africa: Volume II: Vegetables. Washington, DC: The National Academies Press. https://doi.org/10.17226/11763
[6] Ngwuta, A.A., C.B. Ibeabuchi, E.E. Okoli, G.C. Onyishi, J.C. Harriman, I.J. Ogoke, S.A. Dialoke, C.A. PeterOnoh, P.A. Onoh, M.O. Ofor, B.U. Uzoho and V.N. Onyia (2015). Agronomic Characteristics of Maize Genotypes selected for Fresh Maize Production for Rain Forest Agro-ecology of Southeastern Nigeria. FUTO Journal Series (FUTOJNLS), Vol. 1, Issue 2.

[7] Ngwuta, A.A., Ajala, S.O., Obi, I.U. and Ene-Obong, E.E. (2001): Potential sources of Resistance to Maize stem Borers [Sesamia calamists] (Hampson) and Eldana saccharina (walker)] in local maize population of south-eastern Nigeria. African crop science proceedings, vol. 5. 25-28.

[8] Nwangburuka .C., O.A Denton, O.B. kehinde, D.K. Ojo and A.R POPOOLA (2007).Genetic variability and heritability in cultivated okra (Abelmoschus esculentus (L) Moench). Spanish Journal of Agricultural Research 10(1):123-129.

[9] Obi, I.U (2002). Statistical methods of detecting differences between treatment means and research methodology issues in labouratory and field experiments. $2^{\text {nd }}$ ed. Published by AP Express Publishers limited Nsukka Nigeria.

[10] Richard Yaw Agyaere, Mashark Seidu Abdulani, Samuel Saaka Buah, Emmanuel Ayipio, Samuel Kwame Bonsu and Regine Tchientche Kamga. Growth and Fruit yield of Okro as influenced by Genotypes and Mulch in the Guinea Savannah conditions of Ghana. International Journal of Agronomy, Volume 2017, Article ID 9840130, Pg 6.

[11] Wamanda D.T (2007). Inheritance Studies in Collected Local Okra (Abelmoschus esculentus L.Moench) Cultivars in: combining ability analysis and heterosis on diallel cross of okra. African Journal of Agricultural Research, Vol 5, 2108-2155. 